\title{
GILDA DE MELLO E SOUZA
}

G.M.S. - Se vocês estivessem de acordo, eu gostaria de começar esta nossa conversa retomando um tema que já abordei noutro momento mas não soube desenvolver. $\mathrm{O}$ ano passado, ao relembrar numa das reuniões da SBPC a marca deixada pelos professores franceses nas primeiras turmas da jovem Faculdade de Filosofia, mencionei de passagem a influência decisiva que também foi para nós aquela nova oportunidade de convívio. Convívio não só entre professores e alunos, mas entre colegas. De tal forma que o mundo que então nos foi revelado não se insinuou apenas através das aulas e dos livros, mas de uma infinidade de pequenas brechas: os intervalos dos cursos, a troca de opiniões, a confissão mútua de projetos e dúvidas, tudo que foi cimentando o respeito e a amizade que nos fez tão companheiros pelos anos afora. No pequeno grupo que logo formamos, nenhum de nós se descobriu sozinho. Éramos todos muito jovens para enfrentar de maneira corajosa a nossa verdade; foi em grande parte através do olhar do outro que divisamos a imagem que deveríamos reter de nós mesmos. Hoje eu me pergunto se não foi essa aquiescência que fez de nós um grupo, nos obrigando desde o início a dividir as tarefas, forçando as especializações. Quando resolvemos fazer a revista Clima, quase todos já tinham se encontrado. Mas não estarei começando a entrevista pelo fim?

L. e L. - Então vamos voltar um pouco atrás - vamos voltar ao convívio. Como ele se dava? Qual o perfil dessa sociabilidade a que se referia?

G.M.S. - Essa sociabilidade não tinha propriamente um perfil. Era uma figura de muitas faces, complexas, muito rica. Começava a se desenhar na frequência dos cursos, sobretudo nas aulas do Professor Maugüé, onde

Língua e Literatura, (10-13), 1981-84. 
todo o mundo se encontrava, calouros, veteranos, ouvintes interessados na matéria e senhoras de sociedade. Foi ali que nasceu espontaneamente o nosso grupo, fruto de um conjunto de afinidades e circunstâncias. Em primeiro lugar éramos todos discípulos de Maugüé; em seguida, tinhamos todos mais pendor literário que filosófico; em terceiro lugar - e descontados os matizes variados - éramos todos esquerdizantes; e por último, tínhamos origens sociais equivalentes. Parafraseando Paulo Emílio e o seu talento de cunhar fórmulas, pertencíamos àquele setor da burguesia formado por profissionais liberais, altos funcionários, fazendeiros e industriais médios. Essas injunções nos davam um ar de família, um viés definido de enxergar o real, uma sensibilidade atenta, mas partidária e um pouco ácida, características que mais tarde iríamos surpreendes com apreensão em alguns discípulos mais ingênuos que nos sucederam. Foram essas afinidades que nos uniram e alimentaram o nosso convívio diário.

L. e L - Vocês saíam muito juntos? Onde se encontravam, como se divertiam?

G.M.S. - Saíamos muito juntos. A partir de certo momento, creio que só conseguíamos nos divertir se estivéssemos juntos. Em geral nos encontrávamos no fim da tarde, nas aulas de Maugiée, que por essa altura eram ministradas no $3^{\circ}$ andar do Instituto de Educação da Escola Caetano de Campos, onde funcionavam algumas secções da Faculdade. Era já noitinha quando saíamos dos cursos para a réplica ligeiramente européia da Praça da República de então. Os plátanos, a algazarra dos pardais, o vento frio, o eco francês da voz de Maugüé - que carregando meio curvado a sua inseparável serviette, ia à nossa frente, discutindo a aula com algum aluno - tudo isso nos envolvia numa doce miragem civilizada. Se não tínhamos nenhuma tarefa escolar urgente, seguíamos dali para o nosso quartel-general, a Confeitaria Vienense, na Barão de Itapetininga. Era então que entre um croissant e um ice chocolate alemão (pois ninguém bebia em nosso grupo) combinávamos uma esticada ao cinema, quase sempre um filme francês, já visto e fóra do circuito, que íamos caçar em qualquer cinema de bairro. 
L. e L. - No grupo de vocês, ninguém bebia?

G.M.S. - Não. A essa altura ninguém bebia. O que serviu de chacota a alguns escritores jovens, também assíduos na Vienense, que em mesas vizinhas tomavam elegantemente o seu uísque. Creio que foi Rubem Braga que, querendo nos definir, afirmou então com desprezo que tomávamos leite maltado, namorávamos para casar e casávamos mesmo.

L. e L. - Mas conte dos filmes. Quais os filmes que vocês iam catar pelos bairros?

G.M.S. - Todos esses que vocês hoje em dia têm tanto trabalho para localizar nas cinematecas. Mesmo admirando o grande cinema americano, que no decênio de 30 a 40 estava produzindo obras importantes na comédia elegante, no musical, no western, no policial, nós amávamos acima de tudo o cinema francês. Os filmes de René Clair (Sous les Toits de Paris), Jacques Feyder (Kermesse Héroïque), Renoir (Bas Fonds, La Grande Illusion, Duvivier (La Belle Équipage) e sobretudo Marcel Carné Hotel du Nord, Quai des Brumes, Le Jour se Lève). Gostávamos de tudo, mesmo dos mais comerciais como Sacha Guitry, ou mais pitorescos como Marcel Pagnol, cujos diálogos saborosíssimos muitos sabiam de cór Raimu, Jouvet, Gabin, Ledoux, Pierre Fresnay, Arletty, Vivianne Romance, Michèle Morgan - eram alguns dos nossos atores prediletos.

L. e L. - Quem foi o responsável por essa adesão de vocês ao cinema francês? Paulo Emílio Salles Gomes?

G.M.S. - Acho que não. Já estávamos instalados na voga francesa, quando ele chegou da Europa no fim de 1939. Mas foi com ele sem dúvida que aprendemos a dedicar ao cinema a mesma atenção que dávamos à literatura. $\mathrm{Na}$ verdade fizemos sob a orientação dele um verdadeiro curso de estética cinematográfica, que se iniciou pelo filme mudo nas projeções feitas na sua casa, consolidou-se na fundação do Clube de Cinema em 1940 e culminou em 1941 nos seus admiráveis ensaios de Clima e na canonização de Orson Welles.

L. e L. - As projeções eram feitas em casa de Paulo Emílio?

G.M.S. - As projeções eram feitas na própria casa do Paulo, na rua Veiga Filho, franqueada pela solidariedade afetuosa 
de D. Gilda e do Dr Salles Gomes. Foi nessas sessões encantadoramente artesanais, - que precederam as projeções mais rigorosas, já patrocinadas pelo Clube de Cinema na Faculdade de Filosofia - foi nessas condições precárias, com todo o mundo se acotovelando na sala, esticando o pescoço para enxergar melhor a tela, que tomamos conhecimento da evolução do cinema. Desde Meliès, Carlito, griffith até o expressionismo alemão com Fritz Lang, o surrealismo com Cocteau e Bunuel, os filmes de arte, como Le Ballet Mécanique de Léger. Se não me falha a memória, creio ainda que foi na Veiga Filho que vimos pela primeira vez, extasiados, O Encouraçado Potemkin. Nas três salinhas, apinhadas de gente, havia de tudo: os hóspedes da casa - que eram frenquentes e vinham tanto do Ceará como do Rio Grande do Sul, - o grupo da Faculdade, os parentes da família e uma fauna heterogênea, muito ao gosto do filho da casa, formada por mulheres bonitas, granfinos intelectualizados, jovens concertistas no início da carreira, enfim, por representantes de todos os estratos sociais, de todas as tendências políticas. Pois dentre nós, Paulo Emílio era o único que, levado por uma vitalidade transbordante, precisava circular pelos mais variados segmentos da sociedade.

L. e L. - E que mais vocês faziam? Dançavam, cantavam?

G.M.S. - Dançávamos uma vez ou outra e cantávamos sempre, invariavelmente.

L. e L. - Música popular, erudita? Brasileira ou estrangeira?

G.M.S. - Parece incrível, mas nunca música popular brasileira. E sempre canções francesas, num repertório bastante variado que ia desde cançōes muito antigas, - chansons à boire, peças cômicas e grivoises -, até os sucessos recentes de Maurice Chevalier e Fernandel, terminando numa ou outra canção dilacerada de Edith Piaff, na ária central de Kurt Weil para l'Opéra des Quat'sous.

L. e L. - Que vinha a ser a versão francesa da peça de Brecht.

G.M.S. - Pois é. Como você está vendo, a presença da França nos acompanhava onde quer que fôssemos. Aliás, êste aspecto mundano de nossa vida talvez pareça alienado 
aos olhos da juventude de hoje; no entanto foi incrivelmente formador. Sobretudo para mim.

L. e L. - Porque sobretudo para você?

G.M.S. - Porque eu era muito menina e havia chegado à Faculdade com uma espécie de voracidade, de desejo de saber, de me pôr a par. Aliás foi isso que levou um amigo a diagnosticar em mim, com suave ironia, um "complexo de Lilian Aldwinkle"

L. e L. - Que vem a ser isso?

G.M.S. - Naquele momento - como você irá ver — líamos muito Aldous Huxley, e costumávamos utilizar seus personagens para nos definir mutuamente: descobríamos em $\mathrm{X}$, traços de Burlap, em Y uma analogia acentuada com Philip Quarles, em Z uma clara identificação com Lucy Tantamount - e assim por diante. Ora, Lilian Aldwinkle era um personagem feminino, creio que de Those Barren Leaves, sequioso e atormentado, porque achava que nunca chegava a tempo nos lugares e nos momentos em que as coisas realmente essenciais estavam acontecendo.

L. e L. - E vocês viviam um momento em que tudo estava mesmo acontecendo, não é verdade?

G.M.S. - Pelo menos para mim. Muitos de nós já tinham estado na Europa, alguns conheciam os Estados Unidos e essas experiências culturais os tornavam mais senhores de si, mais apaziguados. Mas eu vivia de olhos muito abertos, sugando a vida, não querendo perder nada. Ora, paradoxalmente, o início da guerra foi, en São Paulo, um período de grande efervecência cultural. Com o bloqueio do Atlântico, as companhias de teatro e balé, que haviam saído da Europa para as tournées costumeiras pela América do Sul, ficaram presas do lado de cá do mundo e viram-se obrigadas a circular, indefinidamente, pelas grandes capitais, Rio de Janeiro, São Paulo, Montevidéu, Buenos-Aires. O Teatro de L'Atelier, por exemplo, dirigido por Jouvet, fez grandes temporadas no Brasil, o que tornou possível conhecer a domicílio alguns dos mais belos espetáculos teatrais da época. Especialmente o repertório recente de Giraudoux, nas montagens inesquecíveis de Christian Bé- 
rard, com Jouvet e Madeleine Ozeray nos papéis centrais. Aliás a Companhia não levava apenas Giraudoux, representava também o repertório clássico - aquele que é privilégio da Comédie Française - e outras obras modernas, como o Dr. Knock de Jules Renard, uma das interpretações mais brilhantes de Jouvet. E havia ainda as récitas de matinée, muito interessantes, compostas em geral de peças curtas. Lembro-me de ter assistido num desses dias a uma pecinha realista de 1 ato, de certo autor secundário do início do século, cujo nome não guardei, mais que me impressionou vivamente pelo desempenho dos atores e a melancolia do tom checoviano. Chamava-se La Folle Journée e descrevia a reencontro de dois antigos companheiros de mocidade, que não se viam há vinte ou trinta anos. E como acontece sempre nesses casos, os dois, que durante aquele tempo todo haviam sonhado com a oportunidade excitante de se reverem e rememorarem juntos o "tempo perdido, posto agora um defronte do outro, não encontravam mais nada a se dizer. A interpretação que Jouvet dava ao personagem era inesquecível, sobretudo quando interrompia de tempos em tempos o diálogo frouxo para examinar o amigo em silêncio e exclamar desencantado, como quem volta de um mergulho ao passado: "Pepère, c'est extraordinaire ce que vous avez grossi!..." Depois da longa expectativa, era só o que conseguia dizer: "Compadre, é extraordinário como você engordou!.

L e L. - E quando ao balé, o que vocês viram?

G.M.S - O grande balé clássico da época: o Ballet de Monte Carlo de Léonide Massine, o Original Ballet Russe do Coronel de Basile, a companhia alemã do Ballet Joos. Os dois primeiros representavam o prolongamento dos espetáculos que tinham sacudido Paris um quarto de século antes, e o terceiro a novidade do balé expressionista, que utilizava muito a mímica e buscava os temas no mundo contemporâneo. A obra prima da companhia era "La Table Verte" caricatura genial da Liga das Nações, que impressionou profundamente Mário de Andrade. Aliás, não seria difícil encontrar na marcação pormenorizada que Mário imaginou para o "Câmara-Ballet", de seu poema coral $O$ Café, traços nítidos dessa admiração - como já lembrou Oneida Alvarenga. 
L. e L. - E que outros acontecimentos culturais marcantes você colocaria, ao lado do teatro, do cinema e do balé?

G.M.S. - A extraordinária exposição de pintura que aportou em São Paulo em setembro de 1940: Cento e Cinquenta Anos de Pintura Francesa. Para muitos de nós, presos a uma cidade provinciana e ainda sem museus, foi a grande oportunidade de tomar conhecimento da maior pintura do século 19 e do início da moderna. A exposição ocupou toda a parte térrea do Prédio Itá, na rua Barão de Itapetininga e durante o tempo que durou foi ali o nosso ponto de encontro. Sobretudo nas tardes de sábado, eu costumava passar horas olhando os quadros, meditando um pouco vertiginosa no meu curioso aprendizado da pintura, que estava se processando de trás para diante - ou melhor, do presente para o passado pois tendo se iniciado na rua Lopes Chaves, sob o impacto violento do "Futebol" de Lhote e do "Homem Amarelo" de Anita estava agora retrocedendo do Cubismo para o Fauvismo, deste para o Impressionismo, para a obra de Courbet, de Délacroix, a esmaltada pintura neo-clássica. Muitas vezes era Lourival Gomes Machado que me acompanhava, fazendo-me compreender as vastas superfícies planas que definiam o espaço das telas de Gauguin, o arabesco sinuoso do desenho que as identificava ao Art Nouveau. Lembro-me ainda dos comentários irreverentes de Ungaretti sobre os nus de Renoir, da bela exposição que Maugüé nos fez certa tarde, retirando do contraste entre duas paisagens de técnicas opostas de Théodore Rousseau todo o drama da pintura moderna, dividida entre a visão romântica, heraclitiana, que só nos permitia ver "a falsa aparência e os reflexos" e a visão clássica, eleática, de desenho rígido. Como você está vendo, foi pela mão dos amadores e não dos profissionais que eu cheguei à pintura.

L. e L - Já que estamos fazendo o registro cronológico de sua iniciação artística, fale um pouco de literatura. Quais eram os livros que vocês liam?

G.M.S. - Bem, este ponto é muito comprometedor, pois revela mais facilmente as vogas da época que a nossa capacidade de discriminação. Porisso prefiro falar sobretudo em meu nome. No grupo havia pessoas eruditas, como era o caso de Ruy Coelho, que aos 20 anos já conhecia 
Proust de cabeça para baixo e se iniciou na crítica literária com um ensaio sobre ele que marcou época. Mas eu era muito ignorante, apenas começava a me cultivar. A única coisa que me consola é que muitos dos livros que eu lia então - muitos dos livros que se liam então - eram os que, na geração de Simone de Beauvoir, estavam em voga em Paris.

L. e L. - Então vocês estavam em boa companhia.

G.M.S - Embora um pouco atrasados. Líamos Maurois com um vago desdém - e bastante Mauriac. Aliás foi com alegria e muito alívio que há algum tempo vi Gérard Lébrun saudar Therèse Desqueiroux como um dos grandes romances franceses de qualquer época. Gostávamos de Julian Green, admirávamos muito Malraux, especialmente La Condition Humaine, mas respeitávamos sobretudo André Gide. Não apenas o romancista de Les faux Monnayeurs, mas o autor das soties, de Le Promethée Mal Enchainé e Les caves du Vatican, enquanto os mais requintados preferiam o Journal e os ensaios. Eu, pessoalmente, lia muito Cocteau e me deliciava também com as novelas de Radiguet, sobretudo Le Bal du Comte d'Orgel. E com Le Grand Meaulnes, de Alain Fournier. Um dia Décio de Almeida Prado me apresentou ao Adolphe de Benjamim Constant que eu continuei lendo sempre, até encontrar muitos anos depois a outra face da moeda, o Portrait de Zélide de Geoffrey Scott, a admirável biografia de Mme. de Charrière.

L. e L - E não liam os ingleses, os americanos?

G.M.S - Líamos. Talvez a leitura mais assídua, mais marcante do período, fosse mesmo a dos ingleses. Sobretudo Aldous Huxley e o hoje ignorado Charles Morgan. Para um do nosso grupo, José de Barros Pinto, - cobra em Estatística, e anos mais tarde prêmio Fábio Prado com - romance $A$ Jangada - os três romances mais importates eram o Contraponto de Huxley, $O$ Lobo da Estepe de Hermann Hesse e U.S.A. de John dos Passos. O Contraponto foi, aliás, o romance de maior prestígio na minha geração, e a voga do livro atingiu leitores de todos os tipos; leitores comuns e exigentes, romancistas e críticos de nomeada. Um desses enganos como o 
que iria se repetir, bem mais tarde, com o Quarteto de Alexandria de Durrell, que conseguiu interessar até um filósofo do nível de Gilles Gaston Granger

L. e L. - E que dizer de um teórico da literatura como Bertil Romberg, que dedicou a ele um capítulo inteiro de seu livro sobre o foco narrativo? Mas voltando ao nosso assunto: ninguém lia Lawrence?

G.M.S. - Lia. Lawrence era muito cotado, sobretudo como o autor de Women in Love. As mulheres admiravam muito as representantes femininas, Virgínia Woolf, Katherine Mansfield e uma jovem escritora hoje esquecida, Rosamond Lehmann.

L. e L. - Quais os americanos que vocês liam?

G.M.S. - Vários. Os que passaram completamente de moda, como Steinbeck, Sinclair Lewis, e os que continuam com prestígio como Hemingway. Acho que pela altura de 1940 Faulkner fez entre nós a sua entrada triunfal com Sanctuary. Quanto aos alemães, além de Hesse, já se falava muito em Thomas Mann. E foi mais ou menos por essa época que Mário Schemberg me deu de presente a tradução francesa de $A$ Metamorfose, livrinho que passando de mão em mão, difundiu Kafka no grupo.

L. e L. - Eu gostaria de voltar um pouco atrás para esclarecer um detalhe quanto à influência francesa que vocês receberam. - Como é que a tendo sofrido tão profundamente vocês não se afrancesaram?

G.M.S. - Creio que não nos afrancesamos porque a influência da Faculdade nos atigiu no momento exato. Quando a Faculdade se fundou em 1934, fazia 12 anos que se havia realizado a Semana de Arte Moderna, e o Brasil já tinha entrado no período de rotinização do Modernismo. O decênio de 20 fôra o da assimilação das influências estrangeiras, do nacionalismo com as suas variadas nuances, da experimentação apaixonada. Mas no decênio seguinte o Brasil já desabrochava com um vigor extraordinário. Para conferir a afirmação basta recorrer a uma cronologia do período e ver o que estava acontecendo. Tomemos 1930. Nesse ano surgiram os seguintes livros de poesia: Libertinagem, de Manuel Bandeira, Alguma Poesia de Carlos Drummond de An- 
drade, Remate de Males de Mário de Andrade, Poemas, de Murilo Mendes. E ainda o ano em que Mario Peixoto lança o filme Limite e Villa-Lobos compõe as $B a$ quianas. Ao lado disso, o romance nordestino, que se iniciara com $A$ Bagaceira de José Américo de Almeida (1928) e O quinze de Rachel de Queiroz (1930), se expande em 1932, com João Miguel, da mesma autora, Caetés de Graciliano Ramos e Menino de Engenho de José Lins do Rego. O ano de 1933 marcará o início dos grandes estudos modernos sobre a realidade brasileira, com o aparecimento de Evolução Política do Brasil, de Caio Prado Jr. e Casa Grande \& Senzala de Gilberto Freyre, a que vão se seguir em 1934 O Negro Brasileiro, de Artur Ramos, e em 1936 Sobrados $e$ Mucambos de Gilberto Freyre e Raizes do Brasil, de Sérgio Buarque de Holanda. Mas vejam com mais vagar o que estava acontecendo em 1934, ano da fundação da Faculdade. Além da publicação de $O$ Negro Brasileiro, já mencionada, surgem as seguintes obras: O $3^{\circ}$ volume da Trilogia do Exílio de Oswald de Andrade e a peça $O$ homem e o Cavalo; Suor de Jorge Amado, Bangüê e Moleque Ricardo de Lins do Rego, São Bernardo de Graciliano Ramos, Calunga de Jorge de Lima e Canto da Noite de Augusto Frederico Schmidt. E para não se ficar apenas na produção literária, é preciso não esquecer que a partir de 1928, mais ou menos, a arquitetura brasileira vinha se fixando com Warchavchik, Lúcio Costa, Niemeyer e Rino Levi; que as artes plásticas, depois de alcançarem prestígio internacional, com a premiação de Portinari nos Estados Unidos (1935), expandiram-se na rotina dos Salões ( $I^{\circ}$. Salão de Maio e Exposição da Família Artística Paulista, em 1937) e na fundação do Serviço do Patrimônio Histórico e Artístico Nacional (1937); e que de meados de 1935 a meados de 1938 a Prefeitura implantava em São Paulo a sua experiência cultural mais fecunda e arrojada, criando o Departamento de Cultura, sob a direção de Mário de Andrade. Desculpe a enumeração de tantos dados e datas, mas não fica mais fácil entender agora porque não nos afrancesamos? E preciso lembrar ainda que a essa altura muitos dos resposáveis pela grande transformação artística do Brasil moderno ainda estavam na força da idade, e circulavam pelas ruas, frequentavam bares e cafés, eram vis- 
tos nos teatros, exposições de pintura, conferências, escreviam nos jornais e nos recebiam em suas casas. Não havia mais condições de alimentar em surdina aquilo que Mário de Andrade chamara um dia "a moléstia de Nabuco"

L e L - De fato, a cultura brasileira já tinha fabricado os anti-corpos para combatê-la com eficácia.

G.M.S - Exatamente. O que nos salvou foi termos testemunhado essa explosão de vigor. Daí em diante foi bem mais fácil encarar a diferença brasileira objetivamente, sem humilhação ou paranóia, através da "pauta" (grille) européia, que a Faculdade de Filosofia estava nos fornecendo. A minha geração se formou na encruzilhada dessas duas grandes influências.

L. e L - Depois dessa digressão oportuna que você acaba de fazer, baseada em dados e datas, eu gostaria de infletir a nossa conversa, de novo, para o campo pessoal em que ela vinha se desenrolando. Isto é, aceitando que a sua geração representa de certo modo o ponto de equilíbrio de duas influências antagônicas, uma européia e outra brasileira, como encarar o seu caso particular em que a influência nacional se encarnava não só na grande figura do Modernismo, mas num membro da família, em cuja casa você morava? Como se conciliaram as duas influências? Mário de Andrade interferiu na sua escolha de abandonar o velho modelo familiar, optando por um novo destino de mulher culta?

G.M.S - De certo modo, interferiu. Como não podia deixar de ser, ele foi uma grande influência em minha vida. Eu vim com doze anos para a casa dele — isto é, a casa da mãe dele, minha tia-avó e madrinha, - e ele, com a generosidade que o caracterizava, acompanhou desde essa época a minha formação. Sem muito alarde, aparentemente sem interferir, mas observando atento os meus gostos e tendências, as vagas aspirações que eu ia deixando escapar no correr das conversas. No princípio foi apenas o meu professor de piano. Todas as semanas, por mais urgente que fossem as tarefas, descia do escritório com o paletó leve de seda listada, que usava em casa, e sentava-se ao piano da salinha de música, para me tomar a lição. Durante um ano eu o vi, bastante 
inquieta, substituir as partituras, na esperança de apreender melhor o meu temperamente. - "Quem sabe você tem mais afinidade com os modernos do que com Mozart", dizia. E abandonávamos as sonatas para tentar "Ma mère l'Oye" de Ravel. Um belo dia me surpreendeu desenhando a lápis de côr uma enorme arara vermelha, que eu ampliara de uma ilustração do Ladies Home Journal. Creio que foi com certo alívio que concluiu, afastando-se um pouco para avaliar melhor minha obra: "Acho que você tem jeito mesmo é pra pintura." Suspendemos sem remorso as aulas de piano e durante algum tempo discutimos se não era o caso de eu começar a aprender desenho. E se falássemos $\mathrm{ccm}$ Anita Malfatti? Mas por aquela altura eu estava mais interessada em escrever Muitas vezes, me apanhando com um livro na mão, olhava por cima de meus ombros e verificando o assunto ou o autor, comentava: "Não perca tempo com isso, isso não vai te adiantar nada." E pouco depois, interrompendo o trabalho, descia do estúdio com outros volumes que escolhara cuidadosamente entre os seus livros. Quando eu estava com os meus 17 ou 18 anos - e portanto, já cursava a Faculdade - como alguém em casa lhe contasse que eu andava fazendo versos, exigiu que eu os mostrasse. Dias depois me devolvia os originais, minuciosamente anotados, com várias sugestões de mudanças e comentários tão agudos sobre a escolha de palavras, que apesar da total mediocridade dos poemas, não tive coragem de jogar fóra o manuscrito. De vez em quando o releio, comovida com aquela prova de exigência e respeito. Mas não fiz mais versos. E agora estou vendo que não respondi sua pergunta. Fiquei divagando e me perdi...

L. e L. - Não faz mal. Eu vou repetir a pergunta: Mário teve alguma influência em sua entrada para a Faculdade?

G.M.S - Na entrada para a Faculdade, propriamente, não, mas ele interferiu na escolha do curso. Minha intenção inicial, já que eu estava interessada em literatura, foi inscrever-me em Letras. Quando comuniquei isso, ele meditou um pouco e ponderou: "Se você tiver vocação literária e quiser mesmo ser escritora, como parece pois isso a gente nunca sabe, você ainda é muito moça - precisa, antes de mais nada, se cultivar. E para tanto o mais acertado é cursar a secção de Filosofia ou 
Ciências Sociais. Porque escrever a gente aprende sozinho, lendo muito, se exercitando todos os dias." Então, como em Ciências Sociais havia a cadeira de Estatística e eu era uma negação em matemática, escolhi Filosofia. Mas muitos de meus amigos fizeram, ao mesmo tempo, as duas secções.

L. e L - À medida que você se integrou na vida universitária e foi se rendendo ao fascínio dos cursos e dos professores, não escapou um pouco à influência de Mário?

G.M.S. - De modo algum. Durante todo o curso universitário ele foi o orientador auxiliar de minhas leituras. Me franqueou a sua admirável biblioteca, permitindo que eu entrasse e saísse livremente de seu estúdio; tirasse à vontade os livros da estante (com a condição de os repor no mesmo lugar); pedisse o auxílio do José Bento - o fiel secretário - sempre que fosse preciso localizar fichas de assunto, e assim por diante. Acho que basta citar um episódio para avaliar quanto a assistência dele significou para mim. Quando eu estava no último ano, o Professor Bastide sugeriu que o meu trabalho final de aproveitamento fosse uma dissertação um pouco mais alentada que as comuns, onde eu utilizasse a documentação já recolhida por Mário de Andrade sobre a religiosidade brasileira. Foi só o que ele propôs. $\mathrm{O}$ resto, a fixação do assunto, a bibliografia, a distribuição da matéria em capítulos, tudo, foi sugerido por Mário. Por essa altura ele já havia deixado o Departamento de Cultura e morava no Rio. Mesmo assim, não se esquecia de mim e de tempos em tempos mandava recados, bilhetes com novas indicações de fichas, referências e sugestões de leituras que ainda não lhe tinham ocorrido, etc. O Professor Bastide só teve notícia do trabalho quando o entreguei, já pronto.

L. e L. - E você guardou esse trabalho? Como se chamava?

G.M.S - Guardei. Chamava-se Culto aos espiritos maus no povo brasileiro. Foi redigindo-o que aprendi a compor uin estudo, e só anos depois, ao escrever minha tese de doutoramento, pude avaliar quanto tinha sido útil esse exercício preliminar, feito aos 20 anos. Acho que este pequeno episódio esclarece bem o papel que ele desempenhou em minha formação. 
L. e L - E naquele tempo, como você projetava o seu destino? O que desejava ser?

G.M.S. - Naquela época eu ainda não sabia exatamente o que desejava ser, sabia com bem mais clareza o que não queria ser. Não queria, por exemplo, ser apenas mãe de família: casar, ter filhos, dirigir a casa, receber e pagar visitas, viver submissa à sombra do marido. Ainda era esse o destino da mulher naquele tempo. O que aquela menina assustada e perplexa queria ser. Queria se cultivar, aprender, pois mesmo sabendo que era sensível e tinha algum pendor literário, ainda se sentia desarmada, sem nenhuma confiança em si. Para ser totalmente sincera, nunca fui tomada daquele ímpeto, que se costumava chamar vocação. Fui me descobrindo um pouco ao acaso, arriscando tentativas, aceitando tarefas, só conseguindo avaliar se era forte ou fraca enquanto fazia. Em geral não projetava, - ia adivinhando o rumo. E precisava sempre do julgamento final do outro. Nessas condições era natural que, em vez de decidir sozinha, esperasse que me impelissem, apostassem em mim. E a partir de certo momento, me atribuíram um certo talento de ficcionista.

L. e L - É verdade, você se lançou em Clima com um conto, não foi?

G.M.S - Um conto longo, que o Sérgio Milliet achou banal, repetindo a maneira do Alcântara Machado. Fiz mais duas ou três tentativas no gênero, e apesar de algumas pesoas afirmarem que eu devia insistir na ficção, de repente, não sei porque, deixei de escrever contos. Aliás, hoje, pensando bem, acho que sei porque abandonei a ficção. Foi essa talvez a minha primeira escolha, o meu primeiro ato de liberdade: me rebelei contra o destino que queriam me atribuir, contra o destino que naquele momento atribuíram geralmente às mulheres inconformadas - a ficção ou os versos. Com certeza eu não quis ser como as outras mulheres, preferi me realizar como um homem. Não sei. Hoje fico pensando se não foi esse pecado de orgulho que moveu toda aquela geração feminina da Faculdade.

L. e $\mathbf{L}$ - E vocês não foram marginalizadas por isso?

G.M.S - Não. Tínhamos até bastante prestígio. É verdade que a relação conosco era ambivalente. Havia um interesse 
franco pelo nosso destino, mas uma disposição bem menor de se apostar nele. Creio que àquela altura os homens, mesmo os do nosso grupo mais restrito, se relacionavam conosco um pouco como um marchand diante de um artista jovem que, embora aparentando talento, ainda está muito no início da carreira para merecer crédito. $\mathrm{O}$ brilho podia ser fogacho de mocidade e com o tempo talvez iluminasse uma bas bleu a mais. E havia tantas envelhecendo pelo foyer dos teatros, pelas exposições de pintura, cortejando os jovens professores franceses no final dos cursos! Também não era saudável ser muito valorizada, pois a confiança excessiva podia estar nos alçando acima de nossas forças, de nossos projetos. Foi bem difícil, para a minha geração, harmonizar a carreira com a realização afetiva.

L. e L. - Você não está axagerando? E o seu caso?

G.M.S. - O meu caso é uma exceção. E se o nosso grupo foi pródigo em encontros afetivos que deram certo, conta poucos casais que conseguiram realizar carreiras paralelas, como hoje é corrente entre os ex-alunos da Faculdade.

L. e L. - Divididas entre valores tão contraditórios, aspirações tão conflitantes, como é que vocês mulheres imaginavam a nova feminilidade? Isto é, como desejavam parecer?

G.M.S. - É difícil generalizar Mas pensando bem, creio que o nosso ideal feminino estaria bem próximo daquele descrito por Mark Gabor (The pin-up, a modest history) que se delineara na Europa no início do século e, nos twenties, desabrochou na flapper. Vocês, que são muito sabidos nesse período, devem se lembrar a que estou me referindo, - àquela mulher cujo comportamento, aparência física e maneira de vestir revela ao mesmo tempo auto-confiança e um misterioso sentimento de recato. Que dá a impressão de independência e energia, mas sem ser masculina. Que conserva a graça embora sem oferecer aos outros a face ostensivamente feminina de uma pin-up girl.

L. e L. - Esse modelo, que você acaba de descrever, correspondia ao ideal das mulheres ou dos homens? Ou ao ideal de ambos? 
G.M.S - Não estou muito certa que fosse o ideal dos homens. Mas creio que era o nosso, e se refletia numa determinada maneira de vestir, - saia, blusa, boina, suéter, tailleur, saltos baixos - num determinado tipo físico, mais anguloso que sensual, personificado na tela por Joan Crawford, Katherine Hepburn, Michèle Morgan, Carole Lombard, a Greta Garbo de Ninotchka. Portanto, um tipo oposto ao das gatinhas da época - como Simone Simon - que talvez gozassem de mais prestígio entre os elementos conservadores do grupo masculino.

L e L - Aprofundando um pouco mais esta linha, que estou achando muito interessante, eu gostaria de perguntar a você se o impacto da Faculdade nessas mulheres, que pareciam dispostas a adotar um novo estilo de vida, produziu em todas o mesmo resultado ou resultados diferentes?

G.M.S - O impacto da Faculdade repercutiu nelas de maneiras variadas, pois atuou em pessoas de formação escolar, ambiente doméstico e temperamento muito diversos. Para simplificar, acho que só devemos levar em conta as que tentaram efetivamente inventar para si um novo destino, a partir da experiência renovadora. Isso, a meu ver, foi feito de acordo com três esquemas básicos. O primeiro, mais radical, - que teria arrebanhado as afirmativas e talvez mais corajosas - foi apagar da memória o velho modelo femnino, que ainda vigorava nas famílias, substituindo-o pelo modelo masculino. Por outras palavras, consistiu em assumir integralmente a carreira intelectual, com todos os sacrifícios afetivos que isso implicava. O segundo, cauteloso, foi tentar um compromisso entre o novo e o velho, optando pela carreira, mas sem radicalismo, quer dizer, procurando preservar alguns traços do modelo convencional, com a realização afetiva e as obrigações familiares dela decorrentes. Era uma solução harmoniosa do ponto de vista humano, mas lenta e incompleta como realização profissional. E o terceiro, conservador, foi voltar à antiga dependência, mas convertendo o papel de prisioneira do lar em secretária dedicada: aquela que localiza as obras na estantes, ficha os assuntos, ajuda em pequenas pesquisas, discute as idéias, passa os 
originais a máquina e se realiza, modestamente, delegando à cabeça do casal as glórias finais .

L. e L. - Talvez esteja faltando na sua tipologia a quarta figura, aquela que, optando pela solução radical, dela não deu conta e se destruiu no processo.

G.M.S. - Acho que você não tem razão, pois a alternativa de uma escolha certa ou errada pode ocorrer nas três categorias, e dando-se a última hipótese, a consequência será o ressentimento em suas variantes infinitas, a mania de perseguição, o bloqueio, a revolta. Apenas um exemplo. Há alguns anos atrás, recebi de uma grande intelectual brasileira, que por livre decisão passara a vida organizando, desenvolvendo e muitas vezes redigindo trechos longos do legado de seu mestre, uma confissão surpreendente. Como eu elogiasse entusiasmada 0 desprendimento que a levara a se apagar, para que a fama do amigo resplandecesse, ela comentou com melancolia: "Pois ele me fez muito mal, acabou me devorando, lentamente." E eu me lembrei então do Prometeu de Gide, oferecendo o fígado, para alimentar a voracidade da águia. E muito difícil assumir integralmente a própria escolha, pois toda escolha é um jogo arriscado em que se perde e ganha.

L. e L. - E a seu ver, entre as escolhas examinadas, qual teria sido a mais sensata, aquela em que se ganhou mais do que se perdeu?

G.M.S. - Levando em conta o momento de transição em que minha geração se situava, acho que a escolha menos traumatizante foi a do segundo tipo. Talvez porque correspondesse melhor ao temperamento feminino, naquela fase precisa de sua evolução, ainda tímido, ambivalente, indeciso entre duas ordens de valores: os que tentava assumir e os que não ousava abandonar

L. e L. - E hoje, qual a solução que você proporia ao problema da liberdade feminina em geral? Uma solução mais radical?

G.M.S. - Não. Não vejo vantagem em reivindicar para a mulher o direito a um destino tipicamente masculino, como se isso fosse uma conquista indispensável. Os argumentos que defendem esse ponto de vista não me convencem. 
L. e L. - Então como você proporia a discussão?

G.M.S. - Eu, pessoalmente, não tenho elementos nem competência para tratar sozinha de um problema tão intrincado, mas se você achar que vale a pena posso pedir socorro a um especialista em minorias, como o Professor Roger Bastide.

L. e L. - Pois vamos lá - peça.

G.M.S - Por ocasião do aparecimento de O Segundo Sexo, na França, Roger Bastide publicou na imprensa brasileira - não me lembro em qual jornal, provavelmente n'O Estado de S. Paulo - dois artigos muito engenhosos, analisando a tese central do livro de Simone de Beauvoir. Como vocês devem estar lembrados, seguindo a pista de Margaret Mead, ela afirmava que a infelicidade da mulher moderna não deriva de sua constituição anatômica, mas de sua situação histórica. Isto é, o problema não estaria vinculado à natureza, mas à cultura. Como a mulher era um ser alienado, obrigado a viver na imanência - a facticidade, como diria Sartre - lhe era vedada a possibilidade de realizar-se na transcendência criadora, privativa do homem. Portanto, a mulher estaria excluída da transcedência e condenada à imanência (facticidade). Contestando esta conclusão, Roger Bastide começa a demolir os argumentos da autora. Não é exato, diz ele, afirmar que a mulher seja o único ser votado à facticidade. De modo geral, muito poucas pessoas conseguem se realizar na transcendência criadora: o operário está alienado à máquina e ao regime social; o camponês está alienado à natureza - e por isso tem um comportamento "mágico" muito semelhante ao da mulher; o funcionário e burocrata estão alienados aos regulamentos. Pois o que caracteriza o mundo moderno é que a economia estabelece entre os seres humanos relações de coisas, relações abstratas, e não de pessoas, de seres concretos. Visto desta perspectiva, o próprio homem pode ser considerado um ser alienado, quando a mulher o trata como coisa, meio de alcançar um objetivo, seja ele o poder, o dinheiro ou a segurança. Enfim, não são apenas as mulheres que vivem na imanência - a maioria dos homens jamais consegue elevar-se à transcendência criadora. Posto isto, e com a malícia que o carac- 
teriza, Roger Bastide começa a contestar a tese de Simone de Beauvoir, retirando agora os argumentos da filosofia da liberdade de Sartre. Ora, segundo esta, o que define o ser humano - seja ele homem ou mulher - é o projeto. Portanto, prossegue ele, para ser livre a mulher não precisa escolher necessariamente o projeto masculino; pode realizar-se livremente dentro do projeto que lhe foi atribuido. E a esse propósito lembra a bela análise que Simone Weil faz de Colette, mostrando que, embora confinada à vida vegetal, a uma vida animal, terrestre, a grande escritora viveu intensamente as suas limitações, retirando delas a sua própria grandeza.

L. e L. - E você endossa os argumentos do Professor Roger Bastide?

G.M.S. - Acho que eles representam um ponto de partida válido para se pensar o problema feminino com objetividade. Sempre tive minhas dúvidas se para ser livre realizar-se na transcendência criadora - a mulher precisava negar tudo o que a História, a Cultura haviam feito dela. Por que motivo era assim tão urgente trocar esse destino que bem ou mal a moldou, pela às vezes desastrada carreira masculina? Por que só enxergar na convivência dos sexos o que é luta, os despojos, as feridas?

L. e L. - De que modo, então, você gostaria de pensar o destino da mulher no mundo contemporâneo?

G.M.S. - Em primeiro lugar, sem ressentimento. Em seguida, procurando preservar a diferença, a nossa identidade. Neste momento não me interessa investigar como e por que, ao longo do tempo, fomos sistematicamente espoliadas. Hoje sabemos que a História não é apenas uma bruxa impiedosa e vingativa, que vai fabricando pelas nossas costas uma quantidade de vítimas. A exploração também gera defesas, formas sutis de resistência, de poupança, a valorização paciente do miúdo, das sobras.

L. e L. - Cuja eficácia foi testada largamente no plano da cultura. Na China, por exemplo.

G.M.S. - Na China, se você quiser. - Por que rejeitar essa sabedoria? A mulher é forte e perigosa, não porque seja fisiológicamente mais dotada e detenha o privilégio de 
engendrar uma vida, mas porque sabe conviver melhor com as coisas, está inserida de maneira harmoniosa no mundo. A visão masculina depende sempre de um certo recuo, exige um ponto de observação privilegiado e como que a cavaleiro do real; a feminina, se dá naturalmente, na linha emaranhada do olhar. Eu diria que a relação do homem com o mundo é semelhante à da tomada cinematográfica panorâmica, em que a câmara móvel apreende do alto, e por isso com grande liberdade de ação, um espaço amplo, onde costumam se desenrolar os episódios graves e majetosos: uma batalha, uma cavalgada, uma greve, um incêndio. A relação da mulher com o mundo é, ao contrário, do tipo da tomada próxima, onde uma câmara fixa, imersa num campo raso, registra todas as coisas como sendo equivalente. No entanto, a fotografia pode, aos poucos, ir movimentando esse espaço morto e indiferenciado, selecionando o foco ora aqui, ora ali, fazendo travelings de aproximação em pequenos detalhes, para revelar uma riqueza escondida, que à primeira vista não se podia supor. Tudo simples, barato, silencioso, sem grua nem figurantes.

L. e L - Não foi uma visão desse tipo que você surpreendeu em Clarisse Lispector?

G.M.S - Foi. Aí está uma escritora admirável, que representa como ninguém essa miopia feminina - cultural que só permite enxergar bem o mundo de muito perto. Concedo que seja uma deficiência, mas é possível, a partir daí, instaurar um estilo. Afinal as mulheres podem ter as qualidades. .dos seus defeitos. Talvez gostem de inventar de outro modo, desprezando o projetos rígidos, excessivamente racionais, para ir experimentando, substituindo, improvisando, adaptando. Sua vocação não é seguir o risco, - como o construtor a receita - como a cozinheira novata - o figurino como a garota sem estilo - ; preferem fazer o percurso inverso, que vai da parte ao todo e leva em conta a oportunidade, o imprevisto, as imposições imperceptíveis dos elementos. É por isso que precisamos ter tudo à mão: as sobras dos molhos na geladeira, os retalhos nas gavetas, os botões de velhas camisas em vidrinhos, e nas caixas inumaráveis fitas, cadarços, flores, linhas, pedaços de sedas, fivelas. Mais dia, menos dia, tudo 
pode servir, porque a norma construtiva da mulher é a combinatória.

L. e L. - Mas você não estaria descrevendo o processo construtivo da vestimenta?

G.M.S - Da vestimenta, da culinária, da decoração - de uma infinidade de realizações plásticas e poéticas dos nossos dias .

L. e L. - Estou notando que os exemplos que você tem dado para definir o processo criativo feminino se reportam às artes menores. A mulher estaria fadada às artes menores?

G.M.S - Talvez. na medida em que a cultura a fez minuciosa, detalhista, sensorial, perfeccionista. (Lembre-se de minha imagem inicial: visão panorâmica masculina, tomada próxima/feminina). É preciso não esquecer que estas características também podem render muito em campos "masculinos", como na antropologia, na psicologia, na pesquisa científica em geral, na clínica, na cirurgia, etc. Mas voltando ao campo artístico, concordo com você que, paradoxalmente, o apego à minúcia e ao bem feito não favorece muito a grande arte.

L. e L. - Pode desenvolver um pouco essa afirmação?

G.M.S. - Posso. E quem sabe terminamos com ela esta conversa que nos está levando bem longe daqueles primeiros tempos da Faculdade de Filosofia. Vou retomar a meada a partir de uma citação de Mário de Andrade - de um trecho curto, inserido numa carta a Murilo Miranda: "O bem feito é próprio de uma cadeira, uma renda, de um minueto, e de um rondó. Talvez o bem feito não se adapte bem à grande obra. A grande obra precisa de uma certa asperidade, e essa asperidade é o que ajuda o caráter gradioso de uma sinfonia, de um Lusíadas, de uma catedral, de um afresco de 20 metros." Embora não goste muito dessa separação entre arte maior e arte menor, que me parece histórica e européia, confesso que este trechinho me tem feito pensar Por temperamento afino muito com os artistas menores, com o capricho de modista com que demoram "limpando" a peça, cortando os fiapos, arrematando pelo avesso, costura por costura, humildemente, para que, 
uma vez pronta, a roupa caía sem uma dobra. Prefiro sempre o bem feito, mas tenho de convir que, conceituando as coisas como Mário de Andrade faz, as mulheres não entrariam no Panteon da Glória. Ficariam de fora, na companhia de Checov, lendo Mrs. Dalloway, contemplando os quadrinhos de Klee, ouvindo atentas a música de Satie. Todas vestidas com um costuminho engalanedo de Chanel, desses que escondem no forro de seda, com delicadeza e modéstia, a parte mais nobre da roupa.

L. e L - Você acaba de citar um romance de Virgínia Woolf. Ora, o romance não é arte menor, é uma das grandes realizações artísticas do século 19 , e as mulheres foram então - e continuam sendo hoje - romancistas admiráveis .

G.M.S - É verdade, mas com poucas exceções as escritoras femininas se destacaram, sobretudo, num certo tipo de narrativa de sala de estar próxima da renda e do rondó. Os grandes romances são masculinos, são obras ásperas e grandiosas. O que me parece estranho - e era aí que eu queria chegar - é que as mulheres estejam se empenhando em assimilar essa maneira direta e dura, justamente no momento em que a grande arte atravessa um período de franca desvirilização. Não me refiro à dessacralização da arte, processo bem mais antigo, que fez a pintura descer, lentamente, do céu à terra, do heróico ao doméstico, - lembre-se a pintura holandesa, de La Tour, Chardin - e que no Cubismo deu à figuração do homem uma importância análoga à dos objetos. Estou me referindo à maneira de tratar os elementos estruturais, o espaço, por exemplo, que como mostra Francastel, abandonou gradativamente a organização racional, euclideana, para dar início às experiências variadas do espaço próximo, do espaço táctil, do espaço fragmentado. Àquelas representações, enfim, que a partir de Léger, ignoram a linha de horizonte, a profundidade de campo, a escala respectiva dos elementos, para associar num mesmo plano, objetos díspares ou pedaços de objetos. Assistimos, portanto, a uma mudança radical na esfera da arte, que se exprime no jogo verbal do poema, na combinatória do módulo, na descrição exaustiva do insignificante feita pelo ro,mance, na temporalidade lenta do filme. E não será 
um fenômeno análogo que também ocorre na filosofia, que temendo ficar aprisionada no sistema, passou a valorizar pensadores como Nietzsche e Gramsci e o discurso fragmentado do propos e do aforisma? Quando o distanciamento histórico permitir que se reveja o século sem parti-pris estético, qual o sentido que o olhar de filósofo da cultura irá desentranhar desse jogo formal, aparentemente gratuito e muitas vezes de grande beleza e força expressiva? Como se irá ler no futuro essa nova maneira de interrogar a realidade, essa redução voluntária de poder sobre o mundo, essa grande renuncia representada pela estética do fragmento, da bricolage e do retalho? Por que razão a miopia, outrora privativa do grupo feminino, terá se instalado na cultura?

L e L - Mas você não estará forçando os fatos, para que eles caibam na sua argumentação, e esquecendo uma das características fundamentais da arte contemporânea que é, justamente, a monumentalidade? Pense um pouco no tamanho das telas nas Bienais.

G.M.S - Não creio que esteja forçando os fatos. As Bienais, longe de desmentir o meu ponto de vista, o esclarecem. Pois o que representam essas telas imensas que, uma vez terminadas e exibidas, ninguém sabe o que fazer com elas? Representam a ampliação do insignificante e jamais o grandioso: um punho fechado, uma árvore solitária, uma cesta de frutas. Estão, portanto, no polo oposto daquelas pequenas telas do Renascimento - características sobretudo da pintura germânica - que conseguiam conter, milagrosamente, num espaço reduzido, uma infinidade de informações e de temas suplementares, dispostos sem alarde à volta do tema central, por exemplo, a descida da cruz. Eram obras que traduziam a complexidade do mundo com emoção, mas em surdina - as de hoje falam aos berros para não dizer nada. Você já deve ter presenciado um fenômeno análogo no teatro, quando ao enfrentar um texto de grande intensidade dramática, o autor com métier prefere dizê-lo num registro contido e em voz baixa, enquanto o novato só consegue interpretá-lo elevando a voz até o grito. As grandes telas que atravancam o espaço das Bienais são, a meu ver, o último estertor com que a autoridade masculina procura mascarar uma estética do 
suborno. Um contra-senso. Em resumo, acho que os homens estão fazendo hoje - mal e com pretensão descabida - o que as mulheres fizeram sempre tão bem, modestamente e conformadas. Não teria sido melhor para todos, ter sabido manter as duas óticas que movimentavam com graça este nosso pobre mundo? Ou quem sabe as coisas já começaram a se inverter e estamos chegando a uma encruzilhada? Pois absortos em jogar dados com Mallarmé, os homens ainda não se deram conta que as mulheres já estão a postos para erguer de novo a Guernica, a Rendição de Breda, O Encouraçado Potemkin, O Sobrevivente de Varsóvia. A História tem dessas coisas. 